\title{
ANALISIS POTENSI EKONOMI DALAM PEMBANGUNAN PERTANIAN KABUPATEN/KOTA DI PROVINSI JAWA BARAT
}

\section{ANAL YSIS OF ECONOMIC POTENTIALS IN AGRICULTURAL DEVELOPMENT OF DISTRICT/CITY IN WEST JAVA PROVINCE}

\author{
Riska Novitasari*, Lies Sulistyowati, Maman H. Karmana \\ Program Pascasarjana Ekonomi Pertanian Universitas Padjadjaran \\ J1. Raya Bandung-Sumedang KM. 21 \\ *Email: riskanovitasari992@yahoo.com \\ (Diterima 11-07-2019; Disetujui 24-07-2019)
}

\begin{abstract}
ABSTRAK
Pertanian di Provinsi Jawa Barat memiliki potensi yang besar, tapi kini sektor tersebut sudah bukan lagi menjadi sektor unggulan. Oleh karena itu, tujuan dari penelitian ini yaitu mengidentifikasi kabupaten/kota di Jawa Barat yang merupakan daerah dengan basis pertanian, serta mengidentifikasi daerah yang berperan untuk dapat memacu pembangunan pertanian di Provinsi Jawa Barat. Penelitian ini menggunakan metode deskriptif kuantitatif, dengan penggunaan data sekunder berupa data time series dari tahun 2013-2017 untuk data PDRB Jawa Barat dan PDRB kabupaten/kota se-Jawa beserta laju pertumbuhannya, serta data pendapatan per kapita Jawa Barat dan pendapatan per kapita kabupaten/kota se-Jawa Barat. Sedangkan analisis yang digunakan yaitu analisis Location Quotinet dan Tipologi Klassen. Hasil penelitian ini menunjukkan bahwa terdapat 14 kabupaten/kota di Jawa Barat merupakan daerah dengan basis pertanian, yaitu: Sukabumi, Cianjur, Garut, Tasikmalaya, Ciamis, Kuningan, Cirebon, Majalengka, Sumedang, Indramayu, Subang, Kabupaten Bandung Barat, Pangandaran, dan Kota Banjar. Berdasarkan analisis tipologi klassen menunjukkan bahwa daerah dengan basis pertanian di Jawa Barat hanya masuk ke dalam tipologi 2, 3 dan 4 yang merupakan daerah maju tapi tertekan, daerah berkembang cepat dan daerah relatif tertinggal, sehingga yang dapat berperan dalam memacu pembangunan pertanian di Jawa Barat yaitu kabupaten/kota dengan tipologi 2 yang meliputi Kabupaten Cianjur, Kuningan, Majalengka dan Kabupaten Bandung Barat.
\end{abstract}

Kata kunci: potensi ekonomi; pembangunan pertanian; Jawa Barat

\section{ABTRACT}

Agriculture in West Java Province has great potential, but now the sector is not a leading sector. Therefore, the purpose of this study is to identify districts/cities in West Java which are region with an agricultural base, and identify region that play a role in spurring agricultural development in West Java Province. This research uses descriptive quantitative method, with the use of secondary data in the form of time series data from 2013-2017 for West Java GRDP and West Java districts/cities GRDP and their growth rates, and income per capita in West Java and income per capita districts/cities in West Java. While the analysis used is the analysis of Location Quotinet and Klassen Typology. The results of this study indicate that there are 14 districts/cities in West Java which are areas with an agricultural base, namely: Sukabumi, Cianjur, Garut, Tasikmalaya, Ciamis, Kuningan, Cirebon, Majalengka, Sumedang, Indramayu, Subang, West Bandung Regency, Pangandaran, and Banjar City. Based on the typology analysis, the class shows that the area with an agricultural base in West Java is only included in typologies 2, 3 and 4 which are region with high income but low growth, high growth but low income, and low growth and low income, so that those who can play a role in spurring agricultural development in West Java are districts/city with typology 2 which covers Cianjur Regency, Kuningan, Majalengka and West Bandung Regency.

Keywords: economic potential; agricultural development; West Java 


\section{ANALISIS POTENSI EKONOMI DALAM PEMBANGUNAN PERTANIAN \\ KABUPATEN/KOTA DI PROVINSI JAWA BARAT \\ Riska Novitasari, Lies Sulistyowati, Maman H. Karmana}

PENDAHULUAN

Sejak tahap permulaan pembangunan sampai sekarang, sektor pertanian adalah sektor yang selalu menjadi pusat perhatian karena merupakan sektor penting yang mendukung pembangunan perekonomian nasional di Indonesia (Rustiadi dan Pranoto, 2007). Hal tersebut dikarenakan pertanian merupakan salah satu perekonomian yang banyak menyentuh masyarakat, terutama masyarakat pedesaan (Arsyad, 2009).

Pertanian di Provinsi Jawa Barat secara umum memiliki potensi yang besar dan bervariasi serta didukung oleh kondisi agroekosistem yang cocok bagi pengembangan komoditas pertanian dalam arti luas yang mencakup tanaman pangan, ternak, ikan, dan hutan, serta diimbangi oleh keberadaan sumber daya manusia yang berkualitas, akan mampu memacu pembangunan sektor pertanian sebagai salah satu potensi andalan daerah Parahiyangan (Pemerintah Provinsi Jawa Barat, 2014). Namun berdasarkan hasil penelitian Mukhyi (2007) menunjukkan bahwa sektor pertanian di Jawa Barat pada tahun penelitian justru sudah tidak lagi menjadi sektor unggulan.

Tabel 1. Kontribusi 5 sektor teratas terhadap PDRB Provinsi Jawa Barat Tahun 2013-2017 (persen)

\begin{tabular}{lrrrrr}
\hline \multirow{2}{*}{ Sektor } & \multicolumn{5}{c}{ Tahun } \\
\cline { 2 - 6 } & $\mathbf{2 0 1 3}$ & $\mathbf{2 0 1 4}$ & $\mathbf{2 0 1 5}$ & $\mathbf{2 0 1 6}$ & $\mathbf{2 0 1 7}$ \\
\hline Sektor Industri Pengolahan & 43,68 & 43,72 & 43,44 & 43,08 & 43,10 \\
Sektor Perdagangan Besar dan Eceran, Reparasi Mobil & 16,25 & 15,98 & 15,77 & 15,59 & 15,48 \\
dan Sepeda Motor & 8,45 & 8,06 & 7,69 & 7,69 & 7,44 \\
Sektor Pertanian, Kehutanan dan Perikanan & 8,03 & 8,06 & 8,16 & 8,11 & 8,27 \\
Sektor Konstruksi & 4,39 & 4,49 & 4,67 & 4,81 & 4,78 \\
Sektor Transportasi dan Pergudangan & & & & &
\end{tabular}

Sumber: Badan Pusat Statistik 2018 (diolah)

Tabel tersebut memperlihatkan bahwa pada tahun 2014, sektor pertanian kehutanan dan perikanan dan sektor konstruksi berada pada angka yang sama, tetapi pada tahun 2015 hingga 2017, sektor konstruksi terus mengalami kenaikan, sedangkan sektor pertanian, kehutanan dan perikanan mengalami penurunan. Hal tersebut mengindikasikan bahwa di Jawa Barat sedang terjadi transformasi struktural dari pertanian ke nonpertanian, sesuai dengan teori Chenery dalam Tambunan (2001) yang mengatakan bahwa pada umumnya transformasi yang terjadi di negara sedang berkembang adalah transformasi dari sektor pertanian ke sektor industri.

Hal ini tentunya perlu perhatian dari pemerintah, khususnya yang menangani sektor pertanian untuk dapat 
terus berupaya meningkatkan kinerjanya dalam melakukan pembangunan pertanian di kabupaten/kota yang basis pertanian. Hal tersebut selain berdampak pada peningkatan pendapatan masyarakat setempat, juga berdampak pula pada menurunnya angka ketimpangan di Provinsi Jawa Barat.

Oleh karena itu, tujuan yang dicapai dari penelitian ini yaitu mengidentifikasi daerah yang merupakan basis pertanian, serta mengidentifikasi daerah yang berperan untuk memacu pembangunan pertanian di Provinsi Jawa Barat.

\section{METODE PENELITIAN}

Metode penelitian yang digunakan yaitu deskriptif kuantitatif, dengan analisis yang digunakan yaitu analisis Location Quotient dan Tipologi Klassen. Analisis ini digunakan untuk melihat kebasisan suatu sektor ekonomi dalam suatu wilayah tertentu (seperti: Nuning Setyowati, 2012; Sanusi Fatah dan Abul Rahman, 2013; Endah Djuwendah, 2016; Karsinah $^{2}$, et.al., 2016; dan Dinar Melani Hutajulu, et.al., 2018). Analisis Location Quotient (LQ) menurut Dedy Makmun dan Sonny (2012) digunakan untuk membantu menentukan kapasitas ekspor perekonomian daerah dan melihat kemampuan daya saing komoditas antar daerah atau sektor unggulan suatu wilayah, sedangkan Emilia dan Imelia (2006) mengemukakan bahwa tipologi daerah pada dasarnya membagi daerah berdasarkan dua indikator utama, yaitu pertumbuhan ekonomi daerah dan pendapatan perkapita daerah.

Location Quetiont (LQ) adalah alat analitis untuk menunjukkan basis ekonomi daerah, terutama dari kriteria kontribusi lokal. Formulasi LQ menurut Bendavid-Val (1991) adalah sebagai berikut:

$$
\mathrm{LQ}=\frac{\mathrm{X}_{\mathrm{r}} / \mathrm{RV} \mathrm{V}_{\mathrm{r}}}{\mathrm{X}_{\mathrm{n}} / \mathrm{RV_{ \textrm {n } }}}
$$

dimana, Xr adalah PDRB sektor pertama di tingkat kabupaten/kota, $\mathrm{RVr}$ adalah total PDRB tingkat kabupaten/kota, Xn adalah PDRB sektor pertama di tingkat provinsi, dan $\mathrm{RVn}$ adalah total PDRB sektor pertama tingkat provinsi.

Analisis Tipologi Klassen digunakan untuk mengetahui perbedaan karakteristik daerah di masing-masing kabupaten/kota dengan membagi daerah menjadi empat kriteria. Keempat kriteria tersebut yaitu daerah dengan pertumbuhan tinggi dan pendapatan tinggi, daerah dengan pendapatan tinggi tetapi pertumbuhan rendah, daerah dengan pertumbuhan tinggi tetapi 


\section{ANALISIS POTENSI EKONOMI DALAM PEMBANGUNAN PERTANIAN \\ KABUPATEN/KOTA DI PROVINSI JAWA BARAT \\ Riska Novitasari, Lies Sulistyowati, Maman H. Karmana}

berpenghasilan rendah, dan daerah dengan pertumbuhan rendah dan berpenghasilan rendah (Radianto, 2003; Kuncoro, 2006; dan Sjafrizal, 2008).

Penelitian ini menggunakan data sekunder yang merupakan data time series selama lima tahun dari tahun 2013 hingga 2017. Data yang dianalisis yaitu data PDRB Jawa Barat dan PDRB kabupaten/kota se-Jawa Barat menurut lapangan usaha ADHK 2010. Kemudian data laju pertumbuhan PDRB Jawa Barat dan laju pertumbuhan PDRB kabupaten/kota se-Jawa Barat menurut lapangan usaha ADHK 2010, dan data pendapatan per kapita Jawa Barat dan pendapatan per kapita kabupaten/kota seJawa Barat.

\section{HASIL DAN PEMBAHASAN}

\section{Analisis Location Quotient}

Setiap kabupaten/kota di Provinsi Jawa Barat memiliki jumlah sektor basis dan leading sector yang berbeda-beda. Suatu sektor dikatakan basis apabila memperoleh nilai $\mathrm{LQ}>1$, hal ini menyiratkan bahwa tingkat spesialisasi dalam sektor tertentu dari masing-masing kabupaten/kota tersebut lebih besar apabila dibandingkan dengan sektor yang sama di tingkat provinsi. Dengan kata lain jika LQ>1, mempunyai arti bahwa sektor ini adalah sektor terkemuka di kabupaten/kota tersebut dan memiliki potensi untuk dikembangkan sebagai pendorong ekonomi lokal. Tetapi apabila suatu kabupaten/kota memperoleh nilai $\mathrm{LQ}<1$, ini berarti bahwa tingkat spesialisasi dalam sektor tertentu dari kabupaten tersebut kurang dari sektor yang sama di tingkat provinsi. Oleh karena itu, sektor tersebut bukan sektor yang dominan dan kurang potensial untuk dikembangkan sebagai pendorong ekonomi lokal, dan apabila nilai $\mathrm{LQ}=1$, ini menyiratkan bahwa tingkat spesialisasi dalam sektor tertentu di suatu kabupaten/kota sama dengan di tingkat provinsi, peran sektor-sektor tertentu di kabupaten/kota tersebut relatif sama dengan peran sektor-sektor di tingkat provinsi.

Dari grafik pada Gambar 1 dapat dilihat bahwa kabupaten/kota yang memiliki jumlah sektor basis yang paling sedikit yaitu Kabupaten Bekasi, dimana kabupaten ini hanya memiliki sektor basis di sektor industri pengolahan dan sektor pengadaan listrik dan gas, dengan leading sector-nya itu yaitu sektor industri pengolahan. Berdasarkan data yang diperoleh dari BPS Kabupaten Bekasi 2018, Kabupaten Bekasi merupakan daerah berbasis industri yang 
memberikan kontribusi industri terhadap pendapatan nasional yang cukup signifikan, dengan nilai ekspor industri besar dan sedang yang tercatat di Kabupaten Bekasi pada tahun 2017 mencapai 20.489.298.541,36 US\$. Selain itu, laju pertumbuhan pada sektor ini di tahun 2017 mengalami percepatan dan mempengaruhi kinerja ekonomi, juga berpengaruh terhadap penyerapan tenaga kerja. Hal tersebut sesuai dengan pendapat (Suparmoko, 2002) yang menyatakan bahwa sektor basis yang berasal dari potensi ekonomi daerah akan mampu mengekspor barang dan jasa ke wilayah-wilayah diluar perekonomian setempat. Diperkuat pula dengan teori basis ekonomi yang mendasarkan pandangan bahwa laju pertumbuhan ekonomi suatu wilayah ditentukan oleh besarnya peningkatan ekspor dari wilayah tersebut (Tarigan, 2012).

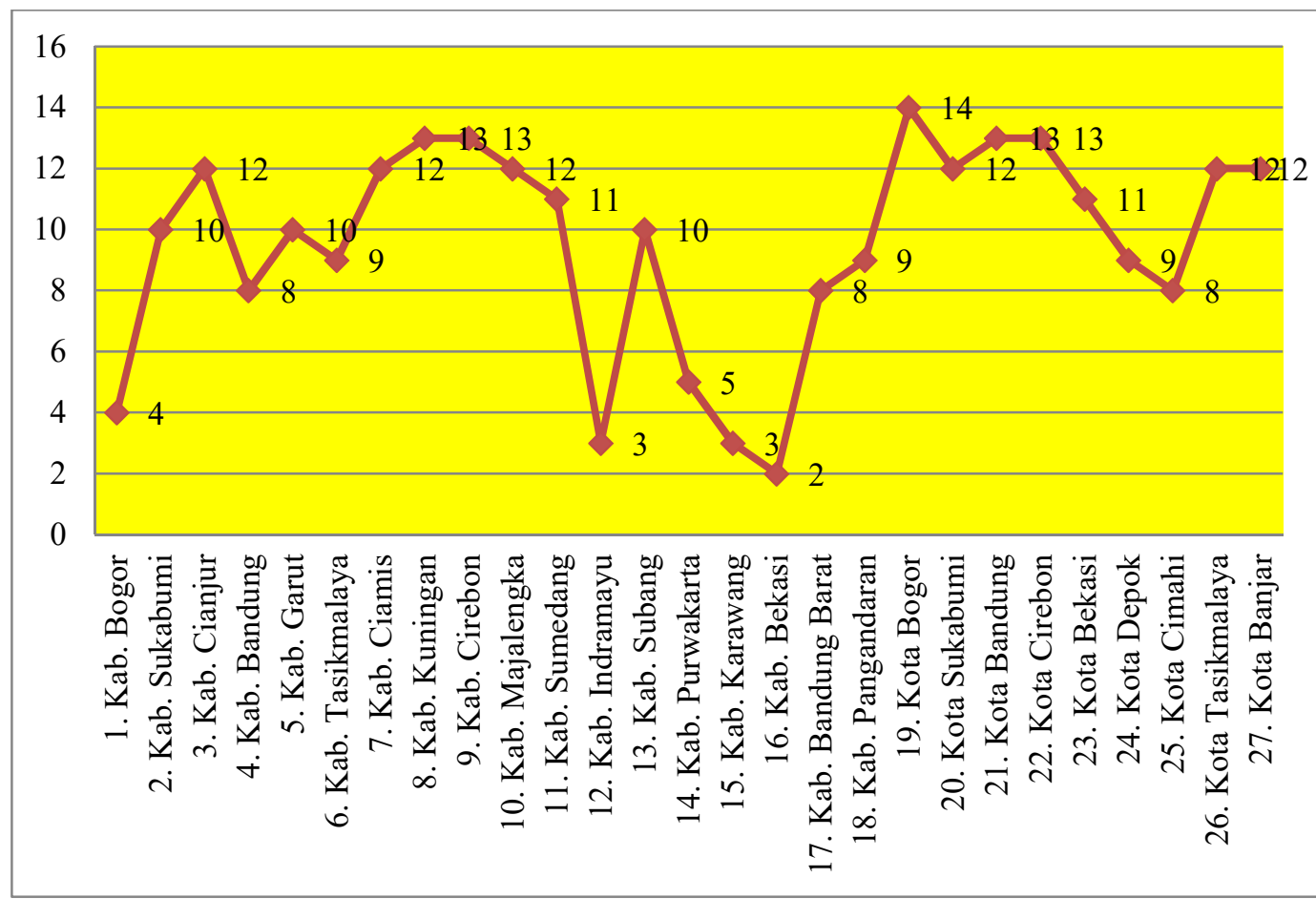

Gambar 1. Grafik jumlah sektor basis kabupaten/kota di Provinsi Jawa Barat

Untuk sektor pertanian, di Jawa Barat terdapat 14 kabupaten/kota yang memperoleh nilai $\mathrm{LQ}>1$, seperti yang dapat dilihat pada Gambar 2. 


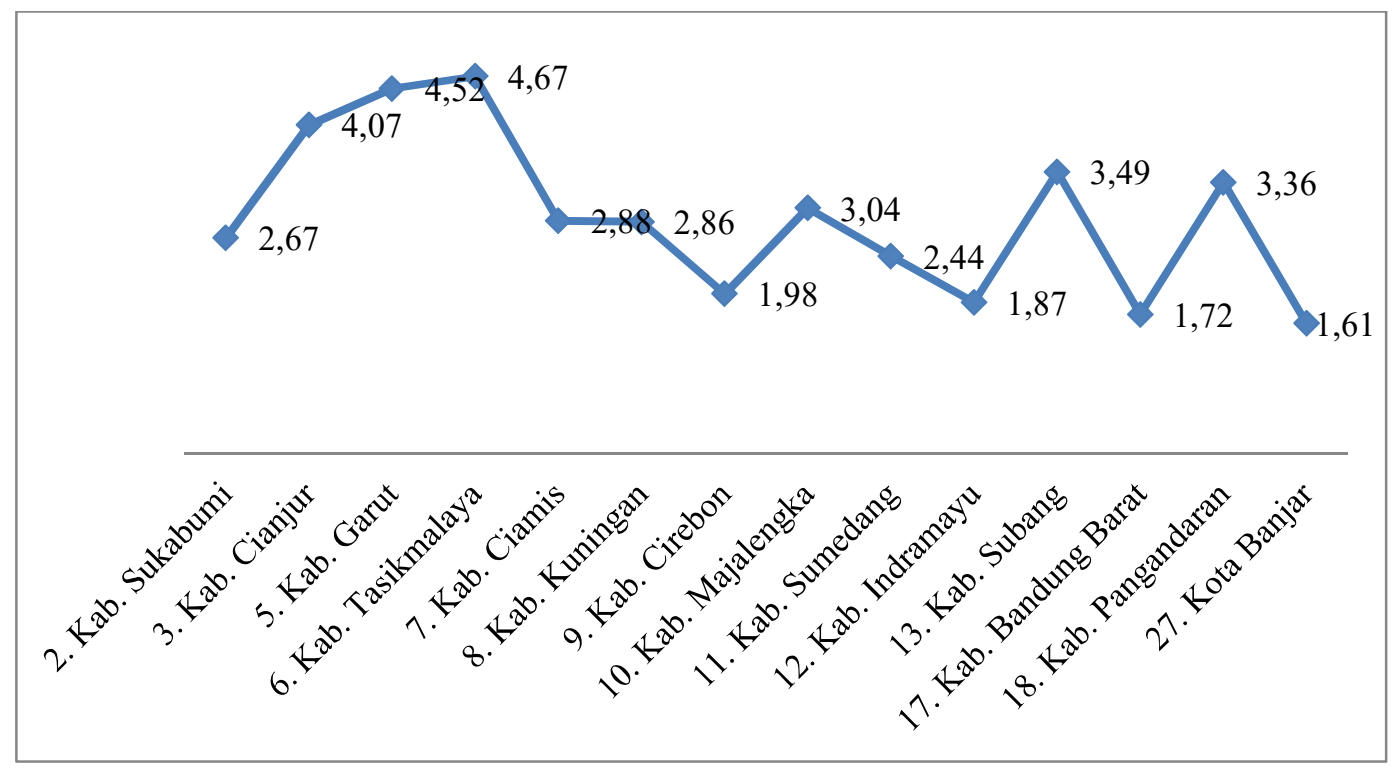

Gambar 2. Grafik kabupaten/kota basis pertanian di Provinsi Jawa Barat

Perolehan nilai LQ yang paling tinggi sebesar 4,67 berada di Kabupaten Tasikmalaya, sedangkan yang paling rendah sebesar 1,61 berada di Kota Banjar. Dari keempat 14 kabupaten/kota yang mempunyai basis pada sektor pertanian, hanya 6 kabupaten yang basis pertaniannya menjadi leading sector. Keenam kabupaten tersebut yaitu: Cianjur, Garut, Tasikmalaya, Ciamis, Majalengka, dan Pangandaran. Secara geografis, kabupaten-kabupaten tersebut berada pada wilayah Jawa Barat bagian selatan, dimana berdasarkan nilai PDRB kabupaten setempat, jika dibandingkan dengan Jawa Barat wilayah lain, wilayah selatan ini memiliki nilai PDRB yang cenderung rendah. Hal itu menjadi salah satu penyebab angka ketimpangan di Jawa Barat terbilang tinggi, seperti hasil penelitian Pritha Aprianoor dan M. Muktiali (2015) yang menunjukkan nilai ketimpangan Jawa Barat tahun 2013 berada pada angka 6,1 dan termasuk pada level tinggi.

Kabupaten Tasikmalaya memperoleh nilai LQ untuk sektor pertanian paling tinggi dibandingkan kabupaten/kota lain di Jawa Barat. Hal tersebut sesuai data dari BPS Kabupaten Tasikmalaya 2018 yang menyebutkan bahwa peranan terbesar dalam pembentukan PDRB Kabupaten Tasikmalaya pada tahun 2017 dihasilkan oleh lapangan usaha Pertanian, Kehutanan dan Perikanan yaitu mencapai 38,00 persen. Kabupaten Tasikmalaya menjadi salah satu daerah di Jawa Barat yang mampu menjaga ketahanan pangan, bahkan kabupaten ini telah mengekspor beras organik ke sejumlah negara. Untuk 
menjaga keberadaan lahan pertanian, Pemkab Tasikmalaya beserta DPRD Tasikmalaya sudah menyepakati penerbitan peraturan daerah tentang sawah abadi. Selain itu, Pemkab Tasikmalaya juga terus berupaya dalam mencetak persawahan baru yang nantinya akan diserahkan kepada masyarakat sebagai penggarap (Media Indonesia, 2017).

Kota Banjar, walaupun memiliki basis pada sektor pertanian, akan tetapi yang menjadi leading sector-nya yaitu sektor administrasi pemerintahan, pertahanan dan jaminan sosial. Hal tersebut terbukti dengan banyaknya penghargaan yang diraih oleh kota ini, diantaranya yaitu peraih penghargaan prestasi kinerja dengan status sangat tinggi tahun 2019, peraih Adipura sebanyak 6 kali, peraih Anugrah Parahita Ekapraya 2018, peraih penghargaan dari Ditjen Perbendaharaan Provinsi Jawa Baat 2018, peraih WTP sebanyak 8 kali dari Menteri Keuangan, dan masih banyak penghargaan lainnya (Pemerintah Kota Banjar, 2019). Banjar merupakan kota pertanian, dimana mayoritas kegiatan perekonomian di Kota Banjar adalah kegiatan ekonomi berbasis pertanian, seperti perkebunan, peternakan, perikanan dan lainnya (Dinas
Perhubungan Komunikasi Informatika dan Pariwisata Kota Banjar, 2014). Maka tidak heran jika Banjar walaupun statusnya merupakan daerah perkotaan, tetapi masih memiliki basis pertanian, sesuai dengan penelitian Riska Novitasari (2015) yang menunjukkan bahwa nilai rata-rata LQ yang diperoleh sektor pertanian dari tahun 2009 sampai 2013 mencapai 1,53. Angka tersebut lebih dari satu, sehingga untuk pertanian termasuk kategori basis.

\section{Analisis Tipologi Klassen}

Tipologi Klassen digunakan untuk menentukan perbedaan karakteristik daerah di setiap kabupaten/kota di provinsi Jawa Barat dalam peninjauan tingkat pertumbuhan dan pendapatan masing-masing daerah. Oleh karena itu, dalam penelitian ini, kabupaten/kota di Jawa Barat diklasifikasikan kedalam empat klasifikasian seperti yang terlihat pada Gambar 3.

Dari Gambar 3 dapat terlihat bahwa kabupaten/kota dengan basis pertanian hanya berada pada tipologi 2, 3 dan 4 . Tipologi 2 merupakan tipologi dengan klasifikasian berupa pendapatan tinggi dan pertumbuhan rendah atau biasa juga yang disebut dengan daerah maju tapi tertekan. Daerah ini merupakan daerah 
yang relatif maju, tapi dalam beberapa tahun terakhir laju pertumbuhannya menurun akibat tertekannya kegiatan utama daerah tersebut. Kabupaten/kota dengan basis pertanian yang masuk dalam tipologi 2 ini yaitu: Cianjur, Kuningan, Majalengkan dan Kabupaten Bandung Barat. Sedangkan yang termasuk dalam tipologi 3 yaitu Kabupaten Indramayu, dimana kabupaten ini memiliki pendapatan yang rendah tetapi pertumbuhannya tinggi dibandingkan dengan rata-rata tingkat provinsi. Daerah ini dapat berkembang cepat karena potensi pengembangan yang dimilikinya sangat besar tapi belum sepenuhnya diolah dengan baik. Dari tingkat pendapatan per kapita yang rendah mencerminkah bahwa pembangunan yang telah dicapai sebenarnya masih relatif rendah. Kemudian untuk tipologi 4 merupakan daerah dengan tingkat pertumbuhan rendah dan tingkat pendapatan per kapita yang juga rendah dibandingkan rata-rata di tingkat provinsi, atau biasa disebut daerah relatif tertinggal. Kabupaten/kota dengan basis pertanian yang termasuk kedalam tipologi 4 yaitu: Sukabumi, Garut, Tasikmalaya, Ciamis, Cirebon, Sumedang, Subang, Pangandaran dan Kota Banjar.

\begin{tabular}{|c|c|c|}
\hline $\begin{array}{l}\text { PRDB per Kapita (y) } \\
\text { Laju pertumbuhan (r) }\end{array}$ & $(\mathrm{y} 1>\mathrm{y})$ & $(\mathrm{y} 1<\mathrm{y})$ \\
\hline \multirow[b]{2}{*}{$(\mathrm{r} 1>\mathrm{r})$} & $\begin{array}{c}\text { Pendapatan tinggi dan } \\
\text { pertumbuhan tinggi }\end{array}$ & $\begin{array}{c}\text { Pendapatan rendah dan } \\
\text { pertumbuhan tinggi }\end{array}$ \\
\hline & $\begin{array}{c}\text { Purwakarta, Karawang, Kota } \\
\text { Bandung, Kota Cirebon dan Kota } \\
\text { Cimahi. }\end{array}$ & Indramayu dan Bekasi \\
\hline \multirow[b]{2}{*}{$(\mathrm{r} 1<\mathrm{r})$} & $\begin{array}{l}\text { Pendapatan tinggi dan } \\
\text { pertumbuhan rendah }\end{array}$ & $\begin{array}{l}\text { Pendapatan rendah dan } \\
\text { pertumbuhan rendah }\end{array}$ \\
\hline & $\begin{array}{c}\text { Bogor, Cianjur, Bandung, Kuningan, } \\
\text { Majalengka, Kabupaten Bandung } \\
\text { Barat, Bogor, Kota Bekasi, Kota } \\
\text { Depok dan Kota Tasikmalaya. }\end{array}$ & $\begin{array}{l}\text { Sukabumi, Garut, Tasikmalaya, } \\
\text { Ciamis, Ciebon, Sumedang, Subang, } \\
\text { Pangandaran, Kota Sukabumi dan } \\
\text { Kota Banjar. }\end{array}$ \\
\hline
\end{tabular}

Gambar 3. Tipologi daerah Jawa Barat menurut kabupaten/kota

\section{KESIMPULAN DAN SARAN}

Berdasarkan analisis LQ, setiap kabupaten/kota di Provinsi Jawa Barat memiliki jumlah sektor basis dan leading sector yang berbeda-beda, tetapi hanya
14 kabupaten/kota yang merupakan daerah dengan basis pertanian, yaitu: Sukabumi, Cianjur, Garut, Tasikmalaya, Ciamis, Kuningan, Cirebon, Majalengka, Sumedang, Indramayu, Subang, 
Kabupaten Bandung Barat, Pangandaran, dan Kota Banjar. Sedangkan berdasarkan analisis tipologi klassen, kabupaten/kota yang dapat memacu pembangunan pertanian di Jawa Barat yaitu Cianjur, Kuningan, Majalengka dan Kabupaten Bandung Barat.

Sehubungan analisis ini hanya dapat mengidentifikasi potensi ekonomi dari masing-masing kabupaten/kota di Jawa Barat, maka dari itu disarankan untuk melakukan penelitian lanjutan mengenai keterkaitan antar sektornya. Hal tersebut dimaksudkan agar sektor yang menjadi basis pada setiap daerah dapat meningkatkan pertumbuhan sektor lain yang non basis di daerah tersebut sehingga pada akhirnya bisa menjadi basis. Kemudian, perlunya campur tangan dari pemerintah terkait implikasi kebijakan yang perlu diterapkan di kabupaten/kota dengan basis pertanian, yang ternyata sebagian besar berada di wilayah selatan Jawa Barat untuk peningkatan ekonomi. Implikasi tersebut bisa berupa peningkatan infrastruktur untuk memfasilitasi hubungan investor dengan daerah terkait, dukungan dan bantuan dari pemerintah, baik itu berupa modal maupun pendidikan, pelatihan dan penyuluhan, menyediakan lembaga permodalan, serta kebijakan lainnya yang mendukung percepatan pembangunan sektor pertanian di Jawa Barat.

\section{DAFTAR PUSTAKA}

Adisasmita, Rahardjo. 2005. Dasar-dasar Ekonomi Wilayah. Graha Ilmu. Yogyakarta

Aprianoor, Pritha dan M. Muktiali. 2015. Kajian Ketimpangan Wilayah di Provinsi Jawa Barat. Jurnal Teknik PWK Volume 4 Nomor 42015

Arifin, Bustanul. 2010. Strategi Pembangunan Pertanian di Indonesia.

https://inspirasitabloid.wordpress.c om/2010/04/30/strategi-

pembangunan-pertanian-indonesial (online). Diakses tanggal 19 Februari 2019

Arsyad, Lincolin. 2004. Ekonomi Pembangunan. Bagian Penerbitan Sekolah Tinggi Ilmu Ekonomi YKPN. Yogyakarta

Arsyad, Lincolin. 2009. Pengantar Perencanaan dan Pembangunan Ekonomi Daerah. BPFE UGM. Yogyakarta

Badan Pusat Statistik Jawa Barat. 2018. Produk Domestik Regional Bruto (PDRB) Provinsi Jawa Barat Menurut Lapangan Usaha Tahun 2013-2017. Bandung

Badan Pusat Statistik Kabupaten Bekasi. 2018. Produk Domestik Regional Bruto (PDRB) Kabupaten Bekasi Menurut Lapangan Usaha Tahun 2013-2017. Bekasi

Badan Pusat Statistik Kabupaten Tasikmalaya. 2018. Produk Domestik Regional Bruto (PDRB) Kabupaten Tasikmalaya Menurut Lapangan Usaha Tahun 20132017. Tasikmalaya

Bendavid-Val, A. (1991). Regional and Local Economic: Analysis for 
Practioners. (4rd ed.). New York: Praeger.

Churiyah, Madziatul. 2006. Model Pembangunan Pertanian melalui Penerapan Agropolitan dan Agrobisnis dalam Meningkatkan Pembangunan Ekonomi Daerah. Jurnal Modernisasi Vol. 2, No. 1 Februari 2006

Deddy M. Dan Sonny I, 2013. Analisis Pergeseran struktur Ekonomi dan Identifikasi sektor potensial wilayah pengembangan, volume 2 nomor 1, April 2013, Jurnal Social Economic of Agriculture. Jurusan Sosial Ekonomi Faperta Universitas Tanjungpura, Kalimanatan Barat

Dinas Perhubungan Komunikasi Informasi dan Pariwisata. 2014. Visi dan Misi Kota Banjar. http://banjarkota.go.id/?Fpage_id= 52 (on-line). Diakses tanggal 18 Maret 2015

Djuwendah, Endah. 2016. Analisis Potensialitas Ekonomi dan Ketimpangan Wilayah di Kabupaten Sumedang. Jurnal Paspalum, Vol. IV, No. 1

Emilia dan Imelia. 2006. Modul Ekonomi Regional. Jurusan Ilmu Ekonomi Fakultas Ekonomi Universitas Jambi. Jambi

Fattah, Sanusi dan Rahman, Abdul. 2013. Analysis of Regional Economic Development in the Regency/Municipality at south Sulawesi Province in Indonesia. Journal of Economic and Sustainable Development, Vol. 4, No. 1

Hutajalu, D. Melani, M. Nasir, dan Arwansyah. 2018. Analysis of the Leading Sector and the Effect of the Economic Growth: a case studi in Pakpak Barat regency, Indonesia. Studia Universitatis "Vasile Goldis" Arab. Economics Series Vol 28: 37-49
Iqbal dan Sudaryanto. 2008. Pembangunan Pertanian Indonesia. https://blogs.unpad.ac.id/abysanila ras/2010/06/13/pentingnyapembangunan-pertanian-diindonesia/ (online). Diakses tanggal 19 Februari 2019

Karsinah $^{2}$, Putri, P.I., Rahayu, K.N., dan Panjiputri, A.F. 2016. The Profil of Pekalongan as a Center of Economic Growth at Tangkallangka Strategic Areas. International Journal of Economics and Financial Issues, 6 (56) 105109

Kuncoro, M. (2002). Analisis Spasial dan Regional: Studi Aglomerasi dan Kluster Industri-Industri. Yogyakarta, Indonesia: UPP AMP YKPN.

Kuncoro, M. (2006). Otonomi dan Pembangunan Daerah: Reformasi, Perencanaan Strategi, dan Peluang. Jakarta, Indonesia: Penerbit Erlangga.

M. A. Mukhyi. 2007. Analisis Peranan Subsektor Pertanian dan Sektor Unggulan terhadap Pembangunan Kawasan Ekonomi Provinsi Jawa Barat: Pendekatan Analisis IRIO. Simposium Nasional RAPI VI 2007 ISSN: 1412-9612. Fakultas Ekonomi Universitas Gunadarma. Depok

Media Indonesia. 2017. Kabupaten Tasikmalaya Perkuat Produksi Pertanian. https://m.mediaindonesia.com/read/ detail/130074-kabupatentasikmalaya-perkuat-produksipertanian (online) Diakses tanggal 10 Juli 2019

Mosher, A.T. 1965. Menggerakkan dan Membangun Pertanian. C.V. Yasaguna, Jakarta

Novitasari, Riska. 2015. Analisis Kinerja Sektor Pertanian dalam Perekonomian Wilayah di Kota 
Banjar. Jurnal Ilmiah Mahasiswa Agroinfo Galuh, Vo. 2, No. 1

Pemerintah Kota Banjar. 2019. Penghargaan.

https://banjarkota.go.ig/penghargaa $\mathrm{n} /$ (online). Diakses tanggal 10 Juli 2019

Pemerintah Provinsi Jawa Barat. 2014. Pertanian.

http://perwakilan.jabarprov.go.id/a rtikel/16/pertanian (on-line). Diakses tanggal 24 Maret 2015

Radianto, E. (2003). Evaluasi Pembangunan Regional Pasca Kerusuhan di Maluku. Jurnal Ekonomi dan Keuangan Indonesia, 51, 479-499.

Rustiadi, E dan Pranoto, S. 2007. Agropolitan Membangun Ekonomi Perdesaan. Crestpent Press. Institut Pertanian Bogor. Bogor
Setyowati, Nuning. 2012. Analisis Peran Sektor Pertanian di Kabupaten Sukoharjo. Jurnal Sepa, Vol. 8, No. 2, 51-182

Sjafrizal (2008). Ekonomi Regional: Teori dan Aplikasi. Padang, Indonesia: Baduose Media.

Suhermanto. 2010. "Analisis Pemetaan Sektor Unggulan dan Strategi Pengembangannya di Kabupaten Sumenep". Program Pascasarjana Universitas Brawijaya. Malang

Suparmoko, M. 2002. Ekonomi Publik untuk Keuangan dan Pembangunan Daerah. Andi Offset. Yogyakarta

Tambunan, T. H. 2001. Perekonomian Indonesia. Penerbit Ghalia. Jakarta

Tarigan, R. 2012. Ekonomi Regional Teori dan Aplikasi Edisi Revisi cetakan keenam. Bumi Aksara. Jakarta 